\title{
The influence of natural and anthropogenic factors on grain size distribution along the southeastern Baltic spits
}

\author{
Gintautas ŽILINSKAS ${ }^{1, *}$, Darius JARMALAVIČIUS ${ }^{1}$ and Donatas PUPIENIS ${ }^{1}$ \\ 1 Nature Research Centre, Akademijos 2, Vilnius 08412, Lithuania
}

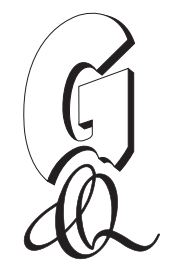

Žilinskas, G., Jarmalavičius, D., Pupienis, D., 2018. The influence of natural and anthropogenic factors on grain size distribution along the southeastern Baltic spits. Geological Quarterly, 62 (2): 375-384, doi: 10.7306/gq.1413

Associate editor: Anna Wysocka

The influence of natural and anthropogenic factors on the distribution of sand grain size along sandy beaches is assessed, based on study of three spits of the southeastern Baltic Sea: the Curonian, Vistula and the Hel. 330 sand samples were collected from the beach and foredune at $1 \mathrm{~km}$ intervals. Our findings show that although the three spits have some characteristics in common, e.g. a predominance of fine- and medium-grained marine sand on their beaches and foredunes, the grain size distribution patterns of the recent sediments along these spits differ significantly. The key factors determining the grain size distribution include the dominant hydrometeorological regime, anthropogenic activity and geological framework. Trends in the mean grain size differentiation along the Vistula and Curonian spits directly correlate with the direction of the longshore sediment transport: as the distance from sources of the longshore sediment transport increases, the size of sand particles, both on the beach and the foredune, decreases. By contrast, on the Hel Spit, this pattern is disturbed in areas of hydrotechnical construction and artificial beach nourishment. Sand differentiation along the beach can also be predetermined by the geological framework, particularly in lithologically anomalous sections, such as the Juodkrantè settlement on the Curonian Spit.

Key words: longshore sediment transport, human activity, geological framework, lithological anomalies, shift regime detection.

\section{INTRODUCTION}

Studies of beach sediment grain size provide information about sediment properties, depositional environment (Visher, 1969; Edwards, 2001; Alsharhan and El-Sammak, 2004; Fenster et al., 2016; Pupienis et al., 2017) as well as the nature and energy flux of the factors influencing sediment transport (Nordstrom, 1975; Gao et al., 1994; Cheng et al., 2004; Barusseau and Braud, 2014; Du et al., 2015).

In the 20th century, many authors used different methods based on grain size parameters to define beach sediment transport patterns and pathways (Stapor and Tanner, 1975; Self, 1977; McCave, 1978; McLaren, 1984; McLaren and Bowles, 1985; Nordstrom, 1989; Pedreros et al., 1996; van Lancker et al., 2004). Different authors (McLaren and Bowles, 1985; Gao and Collins, 1992; Le Roux, 1994; Asselman, 1999) used various methods for the analysis of grain size trends. The two most often distinguished dominant trend types depend on the sedimentary environment and specific sediment transport

\footnotetext{
* Corresponding author, e-mail: zilinskas@geo.It Received: November 16, 2017; accepted: January 30, 2018; first published online: May 8, 2018
}

processes (Le Roux and Rojas, 2007). McLaren (1981) proposed a simple one-dimensional method for the analysis of sediment transport trends, which was later modified by Gao and Collins (1992, 1994) and Asselman (1999). These methods have been widely used to determine sediment transport in different sedimentary environments and are in agreement with direct measurements of processes and numerical modelling results (Mallet et al., 2000; Rios et al., 2002; van Lancker et al., 2004; Hequette et al., 2008; Maillet et al., 2011; Poizot et al., 2013). Sediment trend analysis methods (McLaren and Bowles, 1985; Gao and Collins, 1992) were used to determine patterns of the longshore and cross-shore sediment transport in the Polish, Lithuanian and Russian nearshore zone of the Baltic Sea by Baraniecki and Racinowski (1996), Kairytè and Stevens (2015) and Kovaleva et al. (2016). However, when applying the above-mentioned methods for the determination of sediment transport vectors, researchers often come across unexpected circumstances, e.g. anomalies in lithology or depositional environment and anthropogenic activity, which might be interpreted as divergence or convergence zones of sediment fluxes (Viška and Soomere, 2013; Ostrowski et al., 2014; Kovaleva et al., 2016; Krek et al., 2016). The distribution of beach sand grain size along the Baltic Sea coast on three spits (the Hel, Vistula and the Curonian) has been investigated in part (Žilinskas et al., 2001; Jarmalavičius and Žilinskas, 2006; Kobelyanskaya et al., 2009, 2011; Zhamoida et al., 2009; Rucińska-Zjadacz and 
Rudowski, 2015; Kovaleva et al., 2016; Rudowski et al., 2016; Pupienis et al., 2017). It was found that sand differentiation on the beach is affected by hydrometeorological factors (Kobelyanskaya et al., 2011; Jarmalavičius et al., 2012a; Furmańczyk, 2013; Jarmalavičius et al., 2015; Rucińska-Zjadacz and Rudowski, 2015; Kovaleva et al., 2016), anthropogenic activity (Furmańczyk, 1995; Blazhchishin, 1998; Jarmalavičius and Žilinskas, 2006; Žilinskas et al., 2010; Pupienis et al., 2017) and the geological framework (Furmańczyk and Musielak, 2015; Žilinskas et al., 2016b; Jarmalavičius et al., 2017a). In order to avoid ambiguous interpretations of longshore sediment transport, it is recommended to use several different sediment transport analysis methods and take into consideration statistical validity (Le Roux and Rojas, 2007) when assessing trends.

This paper examines the impact of natural and anthropogenic factors on the distribution of sands of different grain size distribution along beaches based on study of three spits in the southeastern Baltic Sea: Hel, Vistula and Curonian. The aim of the paper is to determine the impact of natural and anthropogenic factors on the distribution of sand of different grain size distributions and to identify lithological anomalies interrupting the continuous longshore sediment transport along the southeastern Baltic Sea spits using sequential grain size data analysis and the regime shift detection method.

\section{STUDY AREA}

The main recent geological geomorphological features of the spits (Curonian, Vistula and Hel) in the southeastern Baltic Sea formed almost simultaneously ( 6.7-6.0 ky), i.e. at the end of the maximal Litorina Sea transgression and during the subsequent period of its regression (Pazdro, 1948; Rosa and Wypych, 1979; Tomczak, 1995; Gudelis, 1998; Badyukova et al., 2007; Damušytè, 2011; Sergeev, 2015). These spits developed from transgression bars (Badyukova et al., 2008, 2017; Furmańczyk and Musielak, 2015), formed by the Holocene sea level fluctuations at the mouths of the historic Baltic Sea rivers (Palaeo-Vistula, Palaeo-Pregolya and Palaeo-Nemunas), and the tops of the eroded historic morainic ridges (between Zelenogradsk-Lesnoy and Rybachy-Ventè Cape) on the Curonian Spit (Gudelis, 1998; Sergeev, 2015). The recent lithological and morphological conditions of these spits are also comparable. The beach predominantly consists of quartzose sand (enriched with heavy minerals) which is related to the Litorina Sea and the Post-Litorina Sea stage (Kobelyanskaya et al., 2009, 2011; Damušytè, 2011; Furmańczyk and Musielak, 2015). On all the spits, the beach is backed by the vegetated foredune. As the tide-ebb amplitude at the southeastern Baltic coasts reaches only $3.5 \mathrm{~cm}$ (Hupfer, 1979), wind-generated waves and aeolian processes are the main beach-forming factors on the Hel, Vistula and Curonian spits (Furmańczyk and Musielak, 1999, 2015; Kobelanskya et al., 2009; Jarmalavičius et al., 2017b).

The $36 \mathrm{~km}$ long Hel Spit is situated in the western part of Gdańsk Bay in the southern Baltic (Fig. 1). The beach width ranges from 25 to $65 \mathrm{~m}$. The elevation of the foredune varies from 2 to $10 \mathrm{~m}$ (Boniecka and Kaźmierczak, 2015), and in some places, reaches $13 \mathrm{~m}$ above sea level (Szmytkiewicz et al., 1999).

The $55 \mathrm{~km}$ long Vistula Spit is separated from the Sambia Peninsula by the Baltiysk Strait (Fig. 1). The northern, $25 \mathrm{~km}$ long part of the spit belongs to Russia and the southern part (30 km long) to Poland. The beach width varies from $10 \mathrm{~m}$ in the northeastern part to $43-45 \mathrm{~m}$ in the central and southwestern parts. The beach is backed by one or two foredune ridges. The relative foredune height varies from 4 to $14 \mathrm{~m}$ (Kobelyanskaya et al., 2011).

The Curonian Spit (98 km long) is located between the Sambia Peninsula and the Klaipeda Strait (Fig. 1). Its northern part (51 km long) belongs to Lithuania and the southern part $(47 \mathrm{~km})$ is within the territory of Russia. The beach width varies from $20-35 \mathrm{~m}$ in the southern to $35-50 \mathrm{~m}$ in the central and $60-80 \mathrm{~m}$ in the northern parts of the Curonian Spit. The elevation of the foredune varies from 4-6 $\mathrm{m}$ in the southern to 7-10 $\mathrm{m}$ in the central and $14-16 \mathrm{~m}$ in the northern parts of the spit. The recent abundance of sand on the northern part of the Curonian Spit is explained by the impact of the Klaipeda port jetties, which intercept longshore sediment drift (Jarmalavičius et al., 2012b).

\section{MATERIAL AND METHODS}

Surface sand samples were collected from the sea shore of the Curonian Spit in the spring of 2014 (196 sand samples), from the Hel Spit of Poland in the summer of 2014 (74 sand samples), and from the Vistula Spit in Poland (60 sand samples) in the autumn of 2014. The sand samples were collected from the middle of the beach (thereinafter referred to as the beach) and the foredune toe (thereinafter referred to as the foredune) at equal $1 \mathrm{~km}$ long intervals (Fig. 2). The methodology of sand sample collection is described in Pupienis et al. (2013) and Jarmalavičius et al. (2015, 2017a). However, sand surface samples were not taken from the Russian part of the Vistula Spit. The sand samples were collected in calm weather conditions (wind speed $<5 \mathrm{~m} / \mathrm{s}$ ). They were dried and then sieved using a "Fritsch Analysette 3 Spartan Pulverisette 0" electric shaker. The grain size statistics were calculated using the GRADISTAT 8.0 interpreter (Blott and Pye, 2001).

The patterns of sand grain size distribution along the beach and the foredune were determined based on the mean sand grain diameter $(d)$ and sorting (So) coefficient. Unlike in previous studies, sand samples were collected at equal distance intervals. Therefore, in data analysis, we could employ the sediment trend analysis method proposed by McLaren (1981) and McLaren and Bowles (1985). According to McLaren and Bowen (1985), sediments should be finer and better-sorted (due to winnowing and selective sand transport) down the transport direction. For the determination of possible discontinuities in series of data on sand grain size variation along the coast, we used the sequential analysis method of regime shift detection (Rodionov, 2004). Although this method is most often employed in time series analysis, it can be adapted to the analysis of spatial data if measurements were carried out at equal distances. It is worth noting that this method may not work if transition from one regime to another is more gradual. In other words, this method is suitable for the identification of abrupt changes (anomalies) in the data series analysed. The analysis was carried out using the regime shift index, where the cut-off length is 5 and the significance level $p=0.05$, which means that all regime shifts with the magnitude of one standard deviation or less will be filtered out if they cover $<5 \mathrm{~km}$ (Radionov, 2004). The $2-3 \mathrm{~km}$ long small-scale erosional-accretionary cells formed along sandy coasts, which are mainly affected by wave processes, reflect the impact of short-term changes in hydrometeorological conditions on sedimentation processes (Homma and Sonu, 1963; Walton, 1999; Pupienis et al., 2016). Since one of the aims of this study was to assess the impact of large-scale longshore sediment 


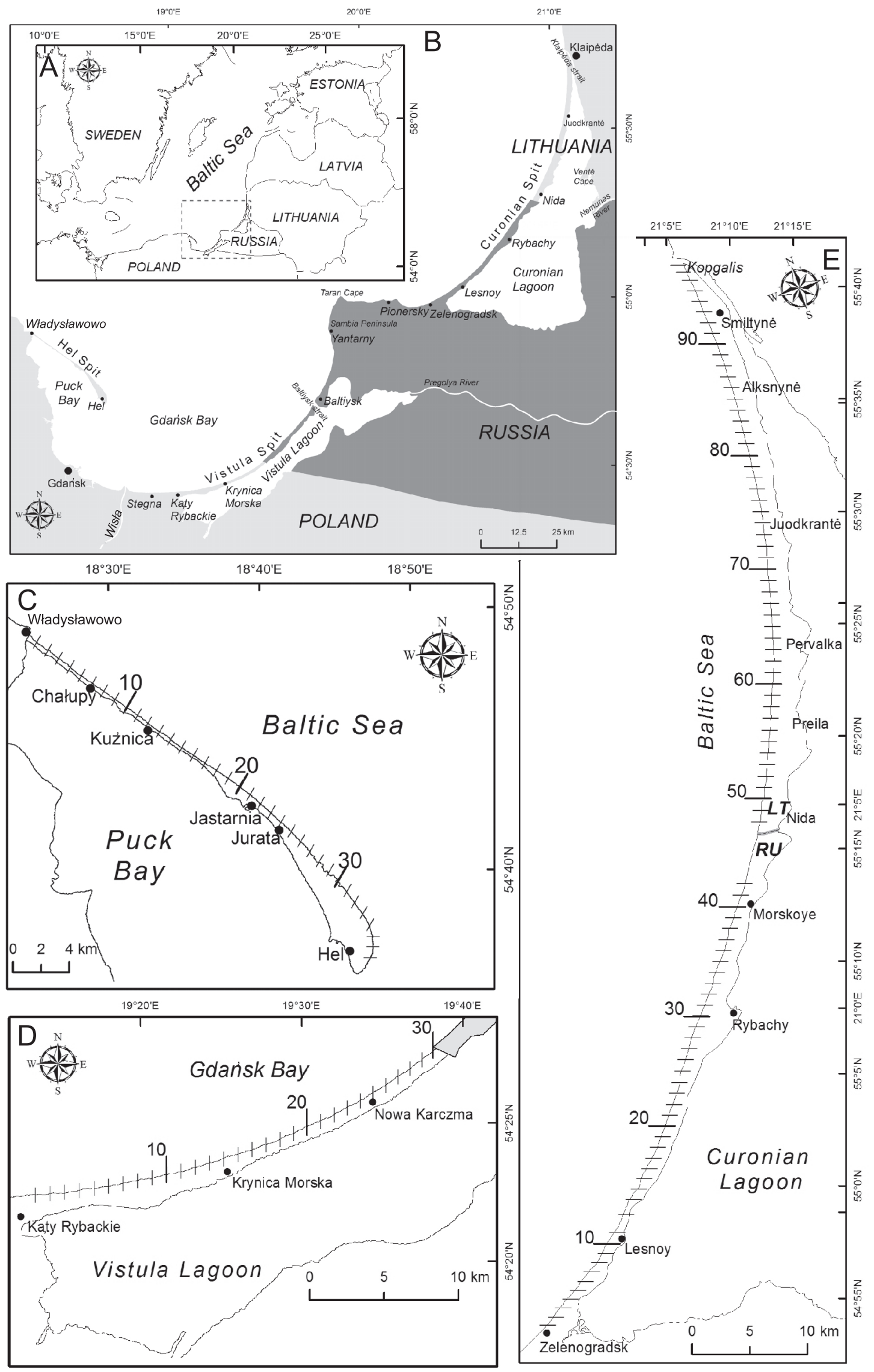

Fig. 1. Location of the study area (A, B); surface sand sample collection sites (dashes) on the $\mathrm{Hel}(\mathrm{C})$, Vistula (D) and Curonian (E) spits 

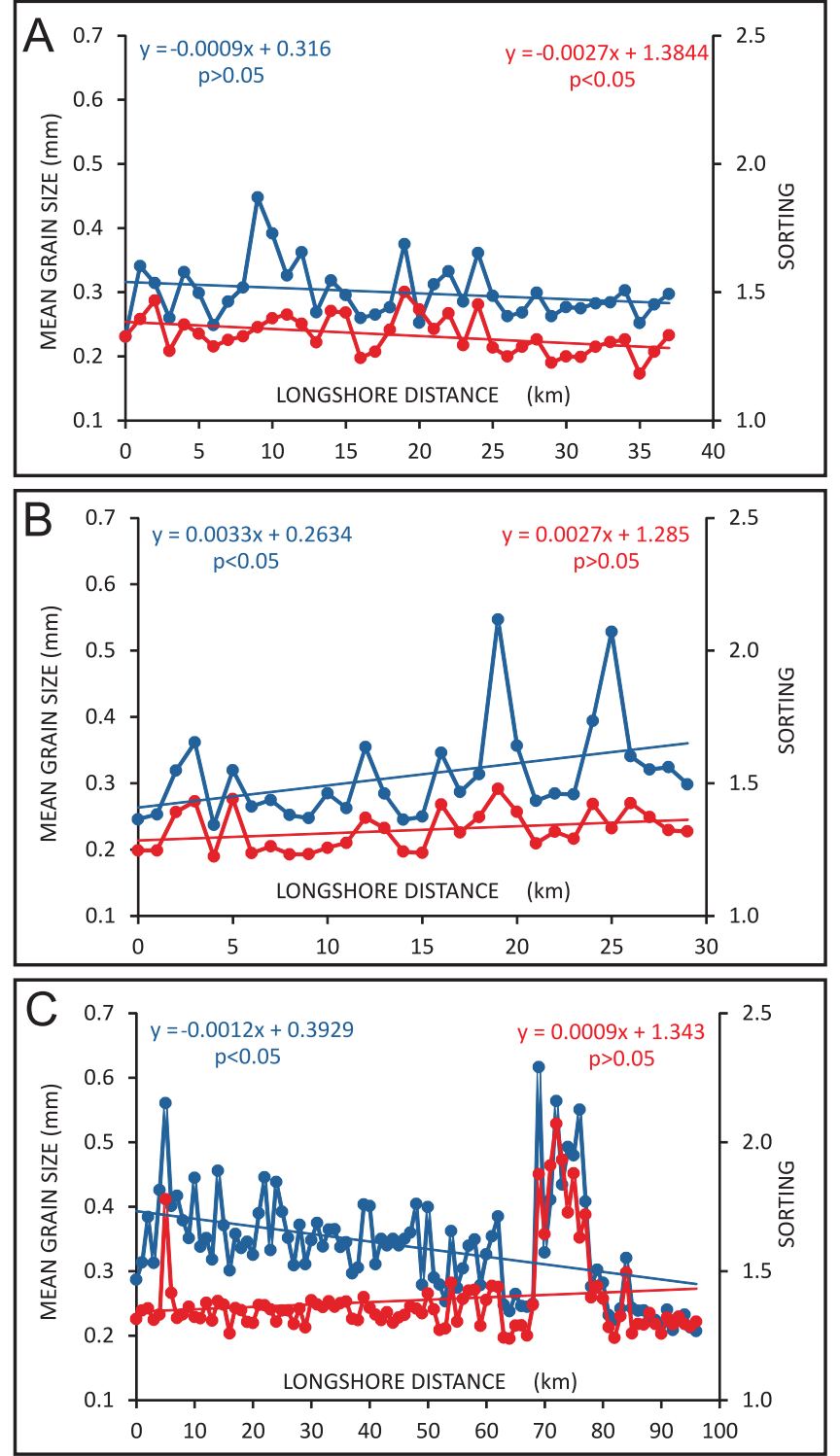

Fig. 2. Longshore variation in mean grain size (1) and sorting (2) on the Hel (A), Vistula (B) and Curonian (C) spits

The longshore distance $(0 \mathrm{~km})$ is shown from spit roots

transport on the distribution of sand particles, in our research we chose the $5 \mathrm{~km}$ cut-off length, i.e. double the averaged erosional-accretionary cell length, to smooth small-scale noise.

\section{RESULTS}

Analysis of the data collected showed that on all the three spits, the coarsest sand accumulates on the beach, and the finest sand on the foredune (Table 1). The beach sand was found to be mainly composed of medium-sized grains. The coarsest sand with a mean grain size $(d)$ of $0.34 \mathrm{~mm}$ dominated the entire Curonian Spit, and the finest sand (mean grain size $d=$ $0.30 \mathrm{~mm}$ ) the Hel Spit. The beach sand on the Polish part of the Vistula Spit was composed of fine-to medium-sized grains with a mean grain size of $0.32 \mathrm{~mm}$. The greatest change in grain
Table 1

Variation in the sand mean grain size $(\mathrm{d}, \mathrm{mm})$ and sorting (So) on the southeastern Baltic spits coast

\begin{tabular}{|c|c|c|c|c|c|c|c|}
\hline \multirow{2}{*}{ Spit } & \multicolumn{2}{c|}{ Hel } & \multicolumn{2}{c|}{ Vistula } & \multicolumn{2}{c|}{ Curonian } \\
\cline { 3 - 8 } & $\mathrm{d}$ & So & $d$ & So & $d$ & So \\
\hline \multirow{4}{*}{ Beach } & $\min$ & 0.23 & 1.18 & 0.24 & 1.22 & 0.18 & 1.24 \\
\cline { 2 - 8 } & $\max$ & 0.45 & 1.50 & 0.55 & 1.48 & 0.78 & 2.07 \\
\cline { 2 - 8 } & mean & 0.30 & 1.33 & 0.32 & 1.33 & 0.34 & 1.39 \\
\hline \multirow{4}{*}{ Foredune } & min & 0.20 & 1.17 & 0.22 & 1.21 & 0.18 & 1.18 \\
\cline { 2 - 8 } & max & 0.31 & 1.51 & 0.40 & 1.45 & 0.49 & 1.52 \\
\cline { 2 - 8 } & mean & 0.26 & 1.26 & 0.27 & 1.29 & 0.30 & 1.32 \\
\hline
\end{tabular}

size $(\sigma=0.08)$ along the coast was recorded on the Curonian Spit, and the lowest on the Hel Spit $(\sigma=0.04)$.

On all the spits, beaches were dominated by well $(1.27<$ So $<1.41)$ and moderately well-sorted sand $(1.41<$ So $<1.62)$; while the most poorly sorted sand was found on beaches of the Curonian Spit (mean So $=1.39)$. The moderately $(1.62<$ So $<2.00)$ and poorly $(2.00<$ So $<4.00)$ sorted sands were confined to Juodkrante beach stretches with the coarsest fraction. The coarse sand $(d>0.50 \mathrm{~mm})$ on the Vistula Spit was well-sorted $(1.27<$ So $<1.41)$ at the 19 th $\mathrm{km}$ and moderately well $(1.41<$ So $<1.62$ ) at the 25th $\mathrm{km}$ of the beach (Fig. 2).

On the all spits, the variety of foredune sands was low with no coarse sand found. On the Vistula Spit, the finest sand $(d<$ $0.25 \mathrm{~mm}$ ) dominated the beach stretch between Katy Rybackie and Krynica Morska (between 0 and the 12th $\mathrm{km}$ ) and the beach stretch between the 79th $\mathrm{km}$ and the distal end (Kopgalis) of the Curonian Spit. Very well (So $<1.27)$, well $(1.27<$ So $<1.41)$ and moderately well $(1.41<$ So $<1.62)$ sorted sand dominated the foredune on all the spits studied (Fig. 2). The smallest variation in the foredune sand grain size was recorded on the Hel Spit $(\sigma=0.04)$, slightly greater $(\sigma=0.06)$ on the Curonian Spit.

No correlation $(r=0.00)$ and very weak $(r=0.22)$ insignificant correlation were determined between mean grain sizes of beach and foredune sands on the Hel and Vistula spits (Fig. 3). However, a statistically significant, strong positive $(r=0.67$; $p<0.05)$ correlation was revealed between mean grain sizes of beach and foredune sands on the Curonian Spit. A significant, moderate positive correlation $(r=0.43 ; p<0.05)$ was determined between the beach and foredune sortings on the Curonian Spit. Meanwhile, on the Hel and Vistula spits, this correlation was very weak and weak positive insignificant. A strong positive significant $(r=0.69 ; p<0.05)$ correlative relationship was detected between the beach mean grain size and the sorting on the Hel and Curonian spits. A very weak positive $(r=0.12)$ correlation between the beach mean grain size and the sorting on the Vistula Spit was not significant at $p<0.05$ (Fig. 3).

The very weak correlative relationship revealed between all the parameters analysed of sand on the Vistula Spit could be explained by a relatively short sampling stretch, because only the Polish part of the spit was surveyed. A weak relationship between the distribution of the foredune and beach sand $d$ (mean grain size) along the Hel and Vistula spit coasts is explained by differences in factors responsible for sand differentiation on the foredune and on the beach. The primary sand grain sorting takes place during the process of sand exchange between the sea and the shore, which is conditioned by the hydrodynamic 

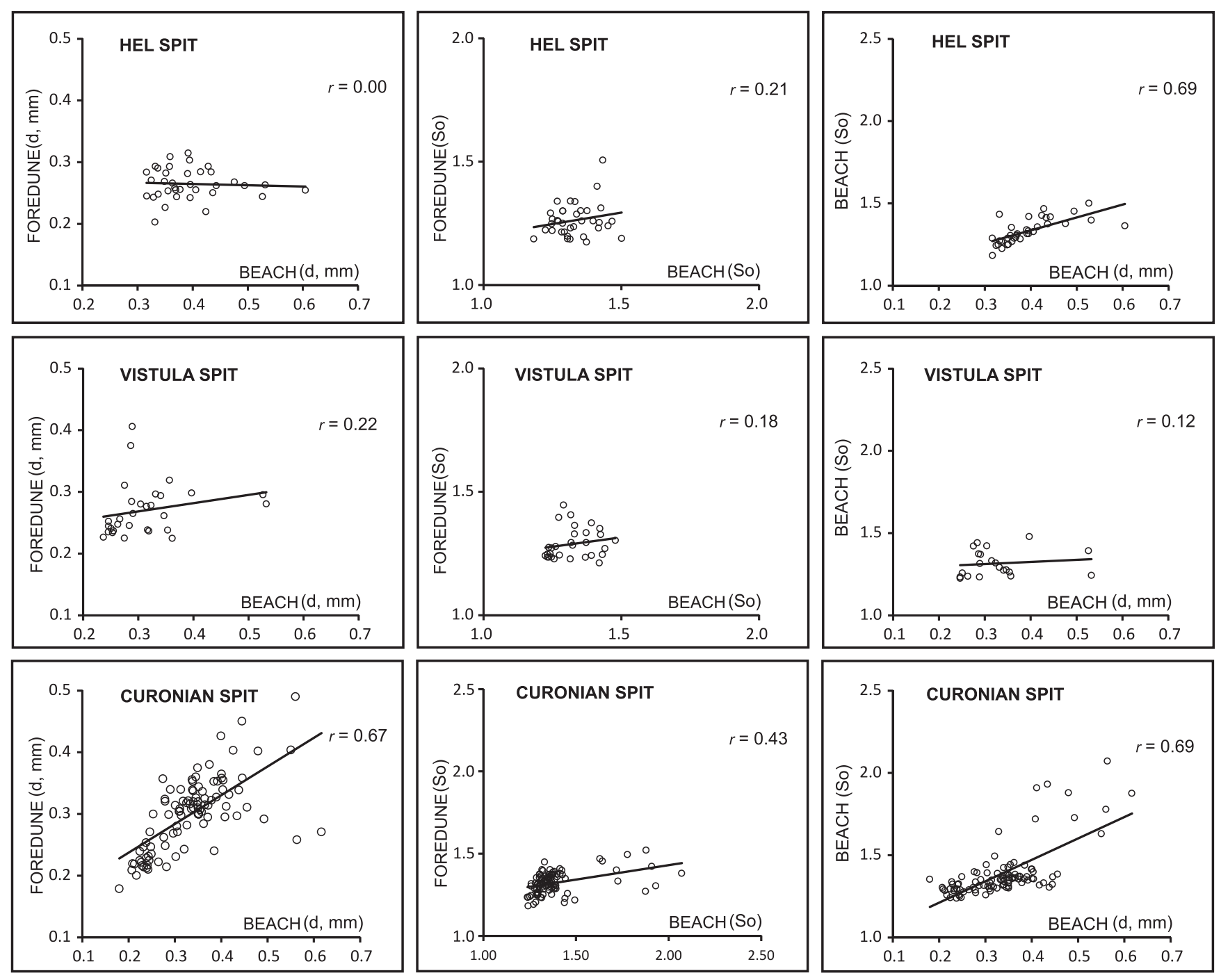

Fig. 3. Relationships between beach and foredune grain size parameters (mean grain size, $d$ and sorting coeficient, So)

regime in the nearshore. Secondary sorting of sand takes place when beach sand is transported by the wind to the foredune. It should be noted that the size of wind-carried sand grains depends on the strength of the winds prevailing in the region and their fetch distance. Therefore, on all the spits investigated, the variety of beach sands and the mean grain diameter were found to be greater than those on the foredune (Table 1). As a result, two environments characterized by different sand compositions are formed on the seashore. Different beach sands are products of the action of hydrodynamic factors (waves, set-up and run-up), while different sands on the foredune are the outcome of aeolian processes. Being products of aeolian differentiation, foredune sands are more homogeneous than beach sands. Consequently, the impacts of the longshore flow, anthropogenic factor and geological framework on the longshore foredune sand differentiation may be not recorded. Therefore, our further analysis is focused on the longshore grain size variation of the beach sand.

The mean grain size of the beach sand on the Curonian Spit tends to become finer in the northern direction and this trend is statistically significant $(p<0.05)$. The linear trend of the beach sand sorting for the entire Curonian Spit coast is statistically insignificant $(p>0.05)$. The same trends were determined for the mean sand grain size and the sorting on the Vistula Spit. However, on the Vistula Spit, these trends follow the opposite direction compared to those on the Curonian Spit, i.e. the sand grain size becomes finer and better sorted in the southwestern direction (Fig. 2). The linear trend of the beach mean grain size is statistically significant $(p<0.05)$ for the entire Hel Spit coast, therefore the sand sorting is statistically insignificant $(p>0.05)$.

The regime shift analysis revealed evident break points in the trend of the mean grain size distribution along the Hel and Curonian spits (Fig. 4). The mean sand grain size on the Hel Spit beach stretch between Władysławowo and the 8th $\mathrm{km}$ is $0.29 \mathrm{~mm}$. Within a short distance (between the 8th and the12th $\mathrm{km}$ ), the beach sand becomes coarser, and the mean grain size significantly increases to $0.38 \mathrm{~mm}$. However, on the beach stretch extending from the 12th $\mathrm{km}$ to the distal end of the spit, the mean grain size decreases to $0.29 \mathrm{~mm}$. Hence, all significant abrupt changes in the mean grain size distribution along the Hel Spit were determined (Fig. 4).

Along the Curonian Spit, we determined three break points in the trend in the mean grain size distribution. We carried out the regime schift analysis and detected significant changes in the mean grain size on the beach stretch between Zelenogradsk $(0 \mathrm{~km})$ and Pervalka (62th $\mathrm{km})$. The average of the 

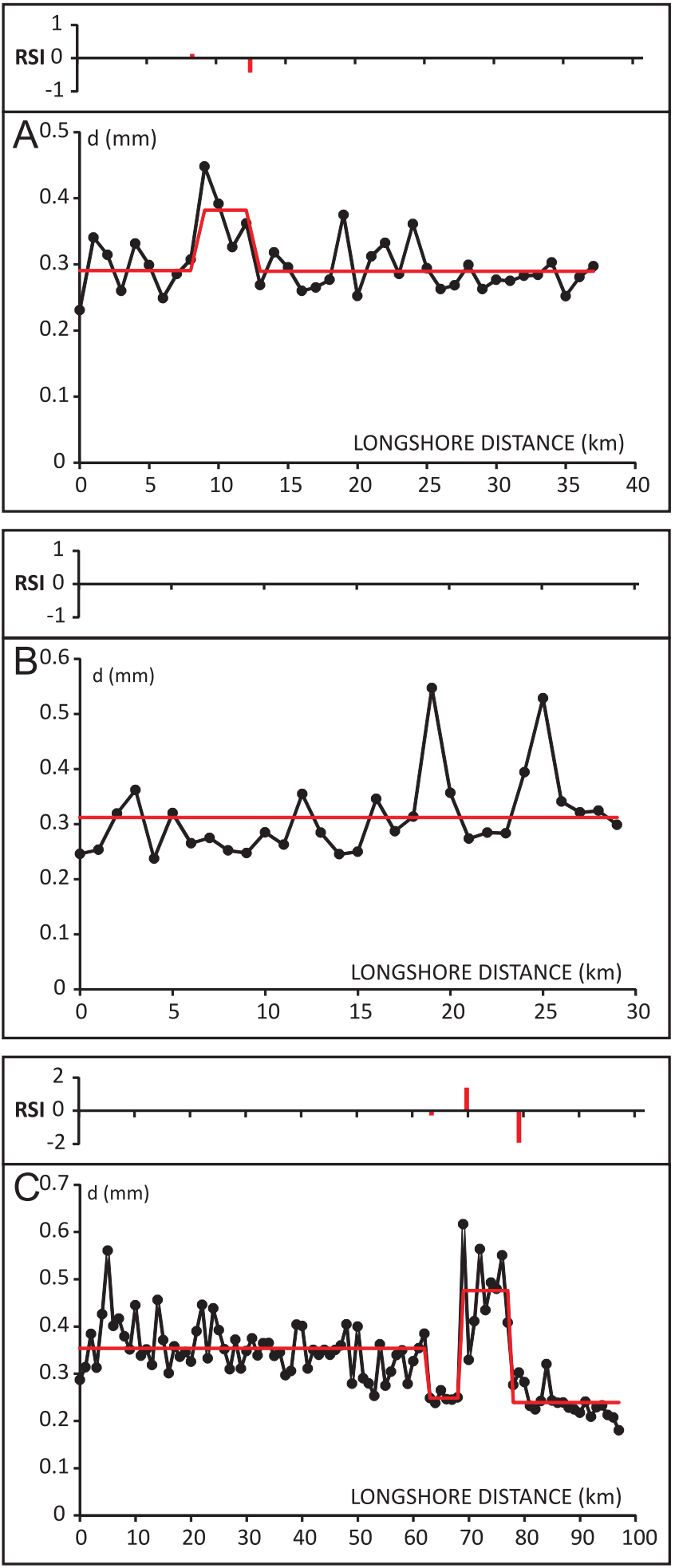

Fig. 4. Regime shifts (red line) detection in the mean grain size (black dotted line) distribution along the $\mathrm{Hel}(A)$, Vistula (B) and Curonian (C) spits

$\mathrm{RSI}$ - regime shift index; the longshore distance $(0 \mathrm{~km})$ is shown from spit roots

mean grain size values on the beach stretch between Zelenogradsk $(0 \mathrm{~km})$ and Pervalka $(62 \mathrm{th} \mathrm{km})$ is $0.35 \mathrm{~mm}$, and it decreases by $\sim 70 \%$ (the average grain size is $0.25 \mathrm{~mm}$ ) within a
$62-68 \mathrm{~km}$ distance. A significant increase of $52 \%$ in the beach mean grain size (from 0.25 to $0.48 \mathrm{~mm}$ ) was recorded on the beach stretch between the 68th and the 77th $\mathrm{km}$ at Juodkrante (Fig. 4). The last abrupt changes in the mean grain size distribution trend were determined on the beach stretch between the 78th $\mathrm{km}$ and the distal end of the Curonian Spit, where the average mean grain size was finer. Over the length of the last surveyed beach stretches, the mean grain size proved to have decreased from 0.48 to $0.24 \mathrm{~mm}$. Hence, no significant changes were determined along the Polish part of the Vistula Spit.

\section{DISCUSSION}

The grain size distribution is a function of hydrometeorological conditions (Sallenger, 1979; Komar and Wang, 1984; McLaren and Bowles, 1985), geological framework (Musielak, 1989; Harris et al., 2005; Badyukova et al., 2007; Damušytè, 2011; Furmańczyk and Musielak, 2015; Sergeev, 2015; Jarmalavičius et al., 2015, 2017b) and recent human activity (Zawadzka, 1996; Ostrowski et al., 2012; Jarmalavičius et al., 2012b; Pupienis et al., 2017). Generally, beach sands tend to become finer and better sorted in the direction of longshore sediment transport (i.e. Vistula and Curonian spits). Coarser sands prevailed on eroded coastal stretches and fine-grained sands on accumulative coastal stretches (Komar and Wang, 1984; Basiński, 1995; Ostrowski and Skaja, 2011; Jarmalavičius et al., 2012a; Pupienis et al., 2017). The dominant hydrometeorological regime is one of the key causative factors in the differentiation of sand grains on the spits during longshore sediment transport (Fig. 5), which depends on prevailing winds and wave direction (Górecka, 1995; Subotowicz, 1995; Babakov, 2010; Ostrowski et al., 2010, 2014; Krek et al., 2016). The insignificant mean grain size trend along the Hel Spit is not indicative of the existing longshore sediment transport because it is affected by human activity. Although the trend in the mean sand grain size distribution along the Hel Spit coast is insignificant, longshore sediment transport was dominant on all the spits investigated. Therefore, according to Subotowicz (1995), the direction of the longshore sediment transport along the Hel Spit is from NW to SE (from the cliffs NW of Władysławowo to the distal end of the Hel Spit). Sediments washed away from the Hel Spit itself and from the respective coastal moraine cliffs act as the source of longshore sediment transport on the Hel Spit (Subotowicz, 1995). The significant trends determined in the mean grain size distribution along the Curonian and Vistula spit coasts coincide with the directions of the longshore sediment transport. Ostrowski et al. (2014) suggest that longshore sediment transport goes in two opposite directions from Cape Taran (the first one southwards from Cape Taran along the Vistula Spit; Fig. 5), the other one northwards from Cape Taran to the distal end of the Curonian Spit (Ostrowski et al., 2014; Krek et al., 2016). Sediments from the eroded western coast of the Sambia Peninsula and the huge sand deposits, accumulated in the 20th century, during the multi-year operation period of the amber mining factory at Yantarny (Boldyrev and Bobykina, 2008), represent sources of southwards sediment transport along the Vistula Spit coast. It should be pointed out that the data presented on the distribution of the mean sand grain size on the Vistula Spit refer only to its southern part (the Polish-Russian border zone). However, the data on the mean sand grain size distribution along the Russian part of the Vistula Spit (Kobelyanskaya et al., 2011) are sufficient to conclude that on this stretch (between the Strait of Baltiysk and the Polish-Russian border zone), the relatively even decrease in sand grain size coincides with the di- 


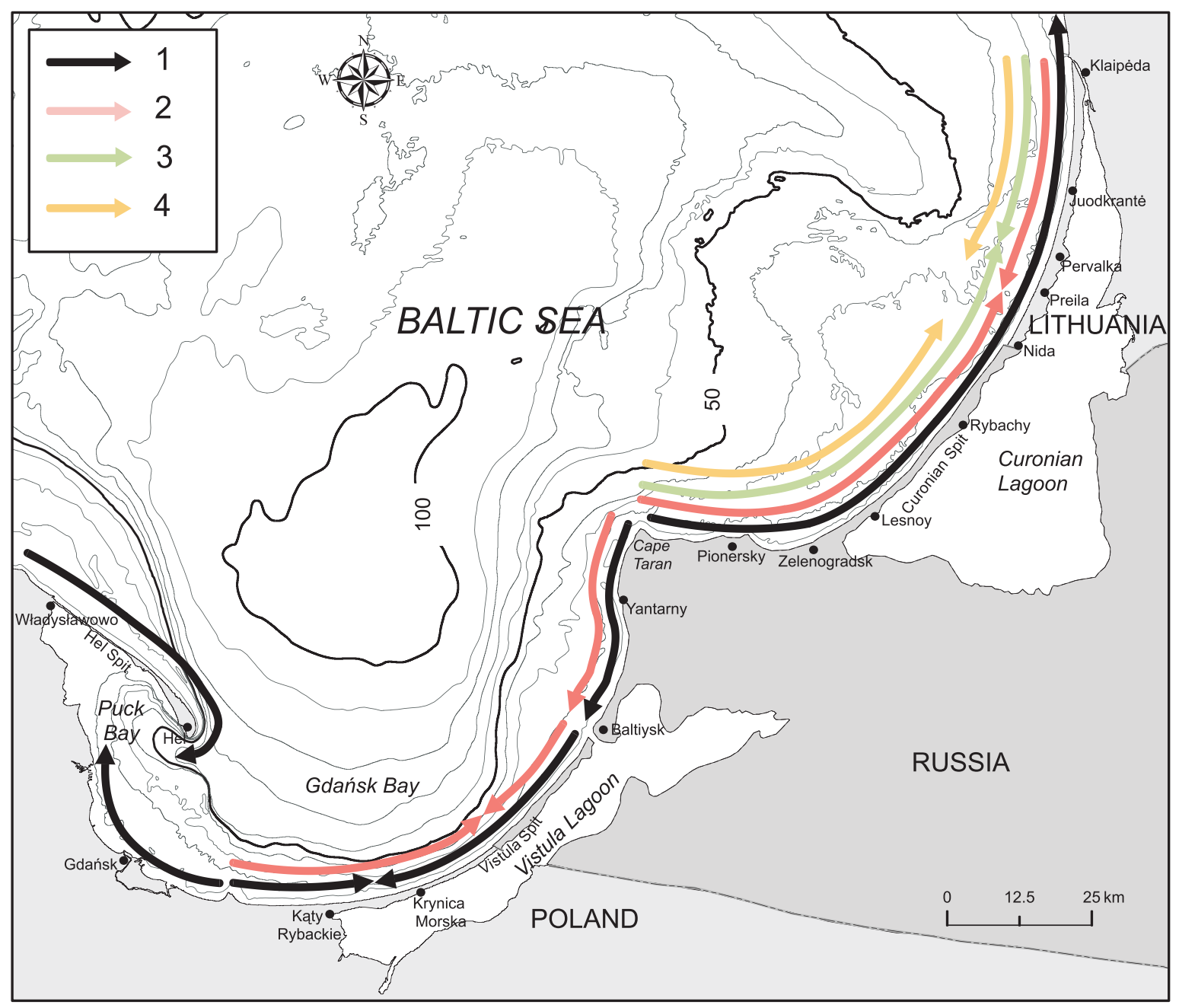

Fig. 5. Direction of alongshore sediment transport

1 - longshore sediment transport according to Knaps (1965), Subotowicz (1995), Jednorał (1996), Ulsts (1998), Zawadzka-Kahlau (1999), Ostrowski et al. (2014), Krek et al. (2016); 2 - longshore sediment transport according to Bogdanov et al. (1986), Bogdanov (2008); 3 - longshore sediment transport according to Kirlys (1968), Gudelis et al. (1977); 4 - longshore sediment transport according to Viška and Soomere (2013)

rection of the longshore sediment transport. According to Ostrowski et al. (2014) and Krek et al. (2016), the sediments washed away from the northern part of the Sambia Peninsula coastal zone represent the source of the northwards longshore sediment transport to the distal end of the Curonian Spit (Fig. 5). Therefore, there is another opinion that there are two opposing sediment flows moving along the Curonian Spit, which, in accordance with the data reported by various authors (Kirlys, 1968; Gudelis et al., 1977; Bogdanov et al., 1986; Viška and Soomere, 2013), converge in the area between Nida and Juodkrantè (Fig. 5).

To prove or reject the existence of flux convergence and divergence on the spits under analysis, we investigated regime shift. The Vistula Spit trend continuity was found to be undisturbed. On the one hand, this pattern suggests a continuous grain size increase along the Vistula Spit. On the other hand, it may indicate that abrupt shifts in trends were not detected because of the Vistula Spit data sample size was too small. However, the Polish researchers Jednorał (1996), Zawadzka-Kahlau (1999) and Ostrowski et al. (2014) stated that the area between Krynica Morska and Kąty Rybackie settlements is a place of convergence of two opposing longshore sediment fluxes (Fig. 5). Bogdanov (2008) argued that the convergence zone along the Vistula Spit occurs near the Polish-Russian border (Fig. 5), but this hypotesis has not been not verified due to a lack of data.

The shift in trend recorded on the Hel Spit on the beach stretch between the 8th and the 12th $\mathrm{km}$ coincides with the end of the groynes field (Fig. 4). On the Hel Spit, groynes stretch from the Władysławowo port to the 12th $\mathrm{km}$. The impact of intense human activity (reinforcement of the coast) is a distinctive feature of the Hel Spit (Basiński, 1995; Zawadzka, 1996; Ostrowski and Skaja, 2011). Moreover, since the 1980s, considerable nourishment of the shore and offshore sediments has been carried out (Zawadzka, 1996; Ostrowski and Skaja, 2011). During the 1989-2010 period, different sectors of the Hel Spit beach were nourished with $\sim 15.4$ million $\mathrm{m}^{3}$ of sand (Ostrowski and Skaja, 2011). As the sand for beach nourishment was dug out from different basins - the Władysławowo port, the Puck Bay and the Baltic Sea (Basiński, 1995), it is obvious that its granular composition was varied and differed from that of the natural sand on the Hel Spit coast. In accordance 
with Zawadzka (1996), the sand obtained from the Puck Bay was well or moderately sorted fine- and medium grain-sized (the mean diameter $-d$ in the range of $0.14-0.24 \mathrm{~mm}$ ), while the sand dug from the Baltic Sea was moderately sorted, but coarser $(d=0.29 \mathrm{~mm})$. Sand grain size differentiation along the coast is impeded by hydrotechnical coastal protection constructions. Meanwhile, the artificial beach nourishment with sediments of inequigranular composition have changed the granular composition of sand in different coastal sectors (Zawadzka, 1996). For instance, at the beginning of the Curonian Spit, on the coastal stretch between Zelenogradsk and the 6th $\mathrm{km}$, there are groynes installed, which do not stop coastal erosion processes. Besides, beach nourishment is not carried out there either (Pupienis et al., 2017). Therefore, unlike on the Hel Spit, the sand there is coarser.

Three trend shifts were determined on the Curonian Spit coastal stretches between the 62-67th, 68-78th and the 79-98th $\mathrm{km}$. Since the longshore sediment transport is often discontinuous, the sediment flux starts unloading and sediments (fine-grained sand) have accumulated on the coastal stretch extending from Pervalka (62-68th $\mathrm{km}$ ) to the Klaipeda port jetties (Knaps, 1965; Ulsts, 1998). Impact of human activity on the grain size distribution was observed in the adjacent sector of the Klaipeda port jetty. The finest sands on the Curonian Spit (between the 78-97th km) concentrate in the southern (windward) part of the Klaipeda port jetty, which is characterized by dominant intense sand accumulation processes (Jarmalavičius et al., 2017a; Pupienis et al., 2017). However, the process of sediment accumulation on the Curonian Spit is interrupted by the geological framework-related lithological anomaly (68-78th $\mathrm{km}$ ). The previous investigations carried out on the Hel, Vistula and Curonian spits (Žilinskas et al., 2016a) established that there exists a geological heritage-induced lithological anomaly on the Curonian Spit. The coarse sand found in the shore section between the 68th and the 78th $\mathrm{km}$ accumulated in the paleo-strait that existed in the Post-Littorina (3.7-2.5 ka BP) period (Žilinskas et al., 2016b; Jarmalavičius et al., 2017a). Coarser sand between Pervalka and Juodkrantè was also found during the investigations conducted in 1994 and 2011 (Jarmalavičius et al., 2017a).

\section{CONCLUSIONS}

The data obtained show that on the three spits analysed (Curonian, Hel and the Vistula), the coarsest sand tends to accumulate in the beach and the finest on the foredune.

The dominant hydrometeorological regime is the determining factor in sand grain differentiation along the coast. On the spits analysed, the trends in mean grain size differentiation along the coasts coincide with the directions of the rlongshore sediment transport: farther from the source of the longshore sediment transport (due to winnowing and selective sand transport), the sand grain size tends to be finer (Vistula and Curonian spits). The relatively even decrease in sand grains farther from the source of longshore sediment transport may be disturbed by hydrotechnical (port jetties) and coastal reinforcement (seawall and bulkhead or revetment) constructions and artificial beach nourishment (Hel Spit). Sand differentiation along the spits may be influenced by the geological framework. The impact of the geological framework is especially noticeable in the coastal zones of lithological anomalies (Juodkrantè settlement on the Curonian Spit).

The method of regime shift index can be employed for the determination of lithological anomalies in sand grain size distribution along the coast.

Acknowledgements. This research was supported by the Lithuanian Science Council (Grant No.MIP-039/2014). Special thanks are addressed to the Geological Quarterly reviewers (R. Ostrowski and one Anonymous reviewer).

\section{REFERENCES}

Alsharhan, A.S., El-Sammak, A.A., 2004. Grain-size analysis and characterization of sedimentary environments of the United Arab Emirates coastal area. Journal of Coastal Research, 20: 464-477.

Asselman, N.E.M., 1999. Grain size trends used to assess the effective discharge for floodplain sedimentation, River Waal, the Netherlands. Journal of Sedimentary Research, 69: 51-61.

Babakov, A., 2010. Wind-driven currents and their impact on the morpho-lithology at the eastern shore of the Gulf of Gdansk. Archives of Hydro-Engineering and Environmental Mechanics, 57: 85-103.

Badyukova, E.N., Zhindarev, L.A., Lukyanova, S.A., Solovieva, G.D., 2007. Geological structure the Curonian Spit (of the Baltic Sea) and its evolution history (revised). Oceanology, 47: 554-563.

Badyukova, E.N., Zhindarev, L.A., Lukyanova, S.A., Solovieva, G.D., 2008. Barrier-lagoon systems in the south-east of the Baltic Sea. Okeanologiya, 48: 641-647.

Badyukova, E.N., Zhindarev, L.A., Lukyanova, S.A., Solovieva, G.D., 2017. Large accumulative forms of relief on the southeastern coast of the Baltic Sea. Oceanology, 57: 580-588.

Baraniecki, J., Racinowski, R., 1996. The application of graining parameters of the rubble from the lower part of the back-swash of the shore stream zone to the determination of evolution ten- dencies of the Wolin island coast. In: Lithodynamics of Seashore (ed. Z. Meyer): 27-38. PAS, Politechnika Szczecińska, Szczecin.

Barusseau, J.P., Braud, R., 2014. Grain-size components as markers of original and depositional processes in the coastal zone of the Golfe du Lion (Mediterranen Sea, France). Journal of Sedimentary Research, 84: 626-644.

Basiński, T., 1995. Protection of the Hel Spit. Journal of Coastal Research, 22: 197-201.

Blazhchishin, A.l., 1998. Anthropogenic influence on the sedimentation in the south-eastern Baltic area (in Russian with English summary). In: Problems of Investigation and Protection of Nature at the Curonian Spit (eds. V.M. Slobodyanik and A.P. Manukian): 68-86. ECAT, Kaliningrad.

Blott, S.J., Pye, K., 2001. Gradistat: grain size distribution ant statistics package for the analysis of unconsolidated sediment. Earth Surface Processes and Landforms, 26: 1237-1248.

Bogdanov, N.A. 2008. Ecological-lithodynamic approach: scientific foundations and methods of estimation of the territories state (in Russian). Ph.D. thesis, Russian State University I. Kanta, Kaliningrad.

Bogdanov, N.A., Aibulatov, N.A., Sharakov, V.P., 1986. Stability level of a modern placer in the outer part of the marine shore 
zone (in Russian with English summary). Lithology and Mineral Resources, 20: 335-344

Boldyrev, V.L., Bobykina, V.P., 2008. Coasts of Vistula and Curonian Spits as transboundary territories: In: Transboundary Waters and Basins in the South-East Baltic (ed. B. Chubarenko): 225-236. Terra Baltica, Kaliningrad.

Boniecka, H., Kaźmierczak, A., 2015. State of shore and backshore on the basis of monitoring results for selected Polish seashores. Bulletin of the Maritime Institute in Gdańsk, 30: 150-163.

Cheng, P., Gao, S., Bokuniewicz, H., 2004. Net sediment transport patterns over the Bohai Strait based on grain size trend analysis. Estuarine, Coastal and Shelf Science, 60: 203-212.

Damušytè, A., 2011. Post-glacial geological history of the Lithuanian coastal area. Ph.D. thesis, Nature Research Centre, Vilnius.

Du, X., Gama, C., Liu, J.T., Baptista, P., 2015. Sediment sources and transport pathway identification based on grain-size distributions on the SW coast of Portugal. Terrestrial Atmospheric and Oceanic Sciences, 26: 397-409.

Edwards, A.C., 2001. Grain size and sorting in modern beach sands. Journal of Coastal Research, 17: 38-52.

Fenster, M., Dolan, R., Smith, J.I.J., 2016. Grain-size distributions and coastal morphodynamics along the southern Maryland and Virginia barrier islands. Sedimentology, 63: 809-823.

Furmańczyk, K., 1995. Coast changes of the Hel Spit over the last 40 years. Journal of Coastal Research, 22: 193-196.

Furmańczyk, K., 2013. Poland. In: Coastal Erosion and Protection in Europe (eds. E. Pranzini and A. Williams): 81-95. Routledge.

Furmańczyk, K., Musielak, S., 1999. Circulation systems of the coastal zone and their role in South Baltic morphodynamics of the coast. Quaternary Studies in Poland, Special Issue: 91-94.

Furmańczyk, K., Musielak, S., 2015. Polish spits and barriers. Coastal Research Library, 12: 181-194.

Gao, S., Collins, M., 1992. Net sediment transport patterns inferred from grain size trends, based on definition of "transport vectors". Sedimentary Geology, 81: 47-60.

Gao, S., Collins, M., 1994. Analysis of grain size trends, for defining sediment transport pathways in marine environments. Journal of Coastal Research, 10: 70-78.

Gao, S., Collins, M.B., Lanckneus, J., De Moor, G., van Lancker, V., 1994. Grain size trends associated with net sediment transport patterns: an example from the Belgian continental shelf. Marine Geology, 121: 171-185.

Górecka, I., 1995. Dynamics of the surface sediments at the sea-floor along the Vistula Spit shoreface. Geological Quarterly, 39 (2): 255-270.

Gudelis, V., 1998. The Lithuanian offshore and coast of the Baltic Sea (in Lithuanian). Lithuanian Academy of Science, Vilnius

Gudelis, V., Kirlys, V., Močiekienè, S., 1977. Littoral drift regime and dynamics along the eastern coast of the Baltic Sea in the off-shore zone of the Curonian Spit according to the data of 1956-1974 (in Russian with English summary). Lietuvos TSR Moksu Akademijos Darbai, B4: 123-128.

Harris, M.S., Gayes, P.T., Kindinger, J.L., Flocks, J.G., Krantz, D.E., Donovan, P., 2005. Quaternary geomorphology and modern coastal development in response to an inherent geologic framework: an example from Charleston, South Carolina. Journal of Coastal Research, 21: 49-64.

Hequette, A., Hemdane, Y., Anthony, E.J., 2008. Determination of sediment transport paths in macrotidal shoreface environments: a comparison of grain-size trend analysis with near-bed current measurements. Journal of Coastal Research, 24: 695-707.

Homma, M., Sonu, C.J., 1963. Rhythmic pattern of longshore bars related to sediment characteristics. Proceedings of 8th International Conference on Coastal Engineering, ASCE: 248-278.

Hupfer, P., 1979. Die Ostsee - kleines Meer mit Grossen Problemen. Teubner Verlagsgesellschaft, Leipzig

Jarmalavičius, D., Žilinskas, G., 2006. Peculiarities of sand sorting on the Lithuanian coast of the Baltic Sea. Geologija, 56: $36-42$.
Jarmalavičius, D., Satkănas, J., Žilinskas, G., Pupienis, D., 2012a. The influence of coastal morphology on wind velocity dynamics. Estonian Journal of Earth Sciences, 61: 120-130.

Jarmalavičius, D., Žilinskas, G., Pupienis, D., 2012b. Impact of Klaipèda port jetties reconstruction on adjacent sea coast dynamics. Journal of Environmental Engineering and Landscape Management, 20: 240-247.

Jarmalavičius, D., Pupienis, D., Buynevich, I.V., Žilinskas, G., Fedorovič, J., 2015. Aeolian sand differentiation along the Curonian Spit Coast, Baltic Sea, Lithuania. The Proceedings of the Coastal Sediments 2015, World Scientific, San Diego: 1-10.

Jarmalavičius, D., Žilinskas, G., Pupienis, D., 2017a. Geologic framework as a factor controlling coastal morphometry and dynamics. Curonian Spit, Lithuania. International Journal of Sediment Research, 32: 597-603.

Jarmalavičius, D., Žilinskas, G., Pupienis, D., Kriaučiănienė, J., 2017b. Subaerial beach volume change on decadal time scale: the Lithuanian Baltic Sea coast. Zeitschrift für Geomorphologie, 61: 149-158.

Jednorał, T. ed., 1996. Dynamics of sea and coastal zone in the Gulf of Gdańsk. Influence of the planned navigable channel in the Polish part of the Vistula Spit on changes of marine hydrodynamic processes on the seaward side of the Vistula Spit (in Polish). Publishers of the Maritime Institute in Gdańsk.

Kairytė, M., Stevens, R.L., 2015. Composite methodology for interpreting sediment transport pathways from spatial trends in grain size: a case study of the Lithuanian coast. Sedimentology, 62: 681-696.

Kirlys, V., 1968. Intensity and direction of sediment transport along the Baltic coast of the Curonian spit (in Russian with English summary). Lietuvos TSR Moksu Akademijos Darbai, B3 (54): 125-132.

Knaps, R., 1965. Sediment Transport along the Eastern Baltic Sea Coasts (in Russian). Latgidroprom, Riga.

Kobelyanskaya, J., Piekarek-Jankowska, H., Boldyrev, V.L., Bobykina, V.P., Stępniewski, P., 2009. The morphodynamics of the Vistula Spit seaward coast (Southern Baltic, Poland, Russia). Oceanological and Hydrobiological Studies, 38: 41-56.

Kobelyanskaya, J., Bobykina, V.P., Piekarek-Jankowska, H., 2011. Morphological and lithodynamic conditions in the marine coastal zone of the Vistula Spit (Gulf of Gdansk, Baltic Sea). Oceanologia, 53: 1027-1043.

Komar, P.D., Wang, C., 1984. Processes of selective grain transport and the formation of placers on beaches. The Journal of $\mathrm{Ge}$ ology, 92: 637-655.

Kovaleva, A., Chubarenko, B., Pupienis, D., 2016. Grain size variability as an indicator of sediment transport alongshore the Curonian Spit (south-eastern Baltic Sea). Baltica, 29: 145-155.

Krek, A., Stont, Z., Ulyanova, M., 2016. Alongshore bed load transport in the southeastern part of the Baltic Sea under changing hydrometeorological conditions. Regional Studies of Marine Science, 7: 81-87.

Le Roux, J.P., 1994. An alternative approach to the identification of net sediment transport paths based on grain size trends. Sedimentary Geology, 94: 97-107.

Le Roux, J.P., Rojas, E.M., 2007. Sediment transport patterns determined from grain-size parameters: overview and state of the art. Sedimentary Geology, 202: 473-488.

Maillet, G.M., Poizot, E., Sabatier, F., Vella, C., Mear, Y., 2011. Pattern of sediment transport in a microtidal river mouth using geostatistical sediment-trend analysis. Journal of Sedimentary Research, 81: 138-152.

Mallet, C., Howa, H.L., Garlan, T., Sottolichio, A., Le Hir, P., Michel, D., 2000. Utilisation of numerical and statistical techniques to describe sedimentary circulation patterns in the mouth of the Gironde estuary. Earth and Planetary Sciences, 331: 1-7.

McCave, I.N., 1978. Grain size trends and transport along beaches: an example from eastern England. Marine Geology, 28: 43-51.

McLaren, P., 1981. An interpretation of trends in grain size measures. Journal of Sedimentary Petrology, 51: 611-624. 
McLaren, P., 1984. The Whytecliff oil spill, British Columbia: sediment trends and oil movement on a beach. Current Research, Geological Survey of Canada Paper, 84-1A: 81-85.

McLaren, P., Bowles, D., 1985. The effects of sediment transport on grain-size distribution. Journal of Sedimentary Petrology, 55: $457-470$.

Musielak, S., 1989. Uwagi dotyczące genezy Półwyspu Helskiego w świetle nowszych badań (in Polish). Studia i Materiały Oceanologiczne, 56: 311-321.

Nordstrom, K.F., 1975. The use of grain size statistics to distinguish between high and moderate energy beach environments. Journal of Sedimentary Petrology, 47: 1287-1294.

Nordstrom, K.F., 1989. Downdrift coarsening of beach foreshore sediments at tidal inlets: an example from the coast of New Jersey. Earth Surface Processes and Landforms, 14: 691-701.

Ostrowski, R., Skaja, M., 2011. Zależność stabilności brzegów Półwyspu Helskiego od sztucznego zasilania (in Polish). Inżynieria Morska i Geotechnika, 6: 495-502.

Ostrowski, R., Pruszak, Z., Skaja, M., Szmytkiewicz, M., 2010. Variability of hydrodynamic and lithodynamic coastal processes in the east part of the Gulf of Gdansk. Archives of Hydro-Engineering and Environmental Mechanics, 57: 139-153.

Ostrowski, R., Pruszak, Z., Schönhofer, J., Szmytkiewicz, M., Szmytkiewicz, P., 2012. Influence of damaged groins on nourished seashore. Proceedings of Coastal Engineering, 33: 1-8.

Ostrowski, R., Pruszak, Z., Babakov, A., 2014. Condition of south-eastern Baltic Sea shores and methods of protecting them. Archives of Hydro-Engineering and Environmental Mechanics, 61: 17-37

Pazdro, Z., 1948. Półwysep Hel i jego geneza (in Polish). Technika Morza i Wybrzeża, 1: 713.

Pedreros, R., Howa, H.L., Michel, D., 1996. Application of grain size trend analysis for the determination of sediment transport pathways in intertidal areas. Marine Geology, 135: 35-49.

Poizot, E., Anfuso, G., Mear, Y., Bellido, C., 2013. Confirmation of beach accretion by grain-size trend analysis: Camposoto beach, Cadiz, SW Spain. Geo-Marine Letters, 33: 263-272.

Pupienis, D., Buynevich, I.V., Jarmalavičius, D., Žilinskas, G., Fedorovič, J., 2013. Regional distribution of heavy mineral concentrations along the Curonian Spit coast of Lithuania. Journal of Coastal Research,65: 1844-1849.

Pupienis, D., Buynevich, I.V., Jarmalavičius, D., Žilinskas, G., Fedorovič, J., Ryabchuk, D., Kovaleva, O., Sergeev, A., Cichon-Pupienis, A., 2016. Density-lag anomaly patterns in backshore sands along a paraglacial barrier spit. Geophysical Research Abstracts Vol. 18, EGU2016-4242-1, 2016 EGU General Assembly 2016.

Pupienis, D., Buynevich, I., Ryabchuk, D., Jarmalavičius, D., Žilinskas, G., Fedorovič, J., Kovaleva, O., Sergeev, A., Cichoń-Pupienis, A., 2017. Spatial patterns in heavy-mineral concentrations along the Curonian Spit coast, south-eastern Baltic Sea. Estuarine, Coastal and Shelf Science, 195: 41-50.

Ríos, F., Cisternas, M., Le Roux, J.P., Correa, I., 2002. Seasonal sediment transport pathways in Lirquén Harbor, Chile, as inferred from grain size trends. Investigations Marinas, 30: 3-23.

Rodionov, S.N., 2004. A sequential algorithm for testing climate regime shifts. Geophysical Research Letters, 31: L09204.

Rosa, B., Wypych, K., 1979. O mierzejach wybrzeża południowego Bałtyku (in Polish). Peribalticum, 1: 31-44.

Rucińska-Zjadacz, M., Rudowski, S., 2015. Morpholithodynamic conditions of the tip of the Hel Peninsula, the Baltic Sea. Oceanological and Hydrobiological Studies, 44: 181-192.

Rudowski, S., Rucińska-Zjadacz, M., Wróblewski, P., Sitkiewicz, P., 2016. Submarine landslides on the slope of a sandy barrier: a case study of the tip of the Hel Peninsula in the Southern Baltic. Geological Quarterly, 60 (2): 407-416.

Sallenger, A.H., 1979. Inverse grading and hydraulic equivalence in grain-flow deposits. Journal of Sedimentary Petrology, 49: 443-562.

Self, R.P., 1977. Longshore variation in beach sands, Nautla area, Veracruz, Mexico. Journal of Sedimentary Petrology, 47: 1437-1443

Sergeev, A., 2015. The history of geological development of the Curonian Spit in the Holocene and modern lithodynamic processes in the coastal zone (in Russian). Ph.D. thesis, A.P. Karpinsky Russian Geological Research Institute, St. Petersburg.

Stapor, F.W., Tanner, W.F., 1975. Hydrodynamic implications of beach, beach ridge and dune grain size studies. Journal of Sedimentary Petrology, 45: 926-931.

Subotowicz, W., 1995. Transformation of the cliff coast in Poland. Journal of Coastal Research, 22: 57-62.

Szmytkiewicz, M., Zeidler, R.B., Różyński, G., Skaja, M., 1999. Modelling large-scale dynamics of Hel Peninsula. Proceedings of Coastal Engineering, 3: 2837-2850.

Tomczak, A., 1995. Relief, geology and evolution of the Hel Spit. Journal of Coastal Research, 22: 181-185.

Ulsts, V., 1998. Latvian coastal zone of the Baltic Sea (in Latvian). Valsts Geolog'ijas Dienests, Riga.

Van Lancker, V., Lanckneus, J., Hearn, S., Hoekstra, P., Levoy, F., Miles, J., Moerkerke, G., Monfort, O., Whitehouse, R., 2004. Coastal and nearshore morphology, bedforms and sediment transport pathways at Teignmouth (UK). Continental Shelf Research, 24: 1171-1202.

Visher, G.S., 1969. Grain size distribution and depositional processes. Journal of Sedimentary Petrology, 39: 1074-1106.

Viška, M., Soomere, T., 2013. Simulated and observed reversals of wave-driven alongshore sediment transport at the eastern Baltic Sea coast. Baltica, 26: 145-156.

Walton, T.L., 1999. Shoreline rhythmic pattern analysis. Journal of Coastal Research, 15: 379-387.

Zawadzka, E., 1996. Coastal zone dynamics during artificial nourishment. Coastal Engineering. Part IV: Coastal Processes and Sediment Transport, 2955-2968. American Society of Civil Engineers, New York.

Zawadzka-Kahlau, E., 1999. Tendencje rozwojowe polskich brzegów Bałtyku Południowego (in Polish). Gdańskie Towarzystwo Naukowe, Gdańsk

Zhamoida, V.R., Ryabchuk, D.V., Kropatchev, Y.P., Kurennoy, D., Boldyrev, V.L., Sivkov, V.V., 2009. Recent sedimentation processes in the coastal zone of the Curonian Spit (Kaliningrad region, Baltic Sea). Zeitschrift der Deutschen Gesellschasft für Geowissenschaften, 160: 143-157.

Žilinskas, G., Jarmalavičius, D., Minkevičius, V., 2001. Eolian processes on the marine coast (in Lithuanian with English summary). Nature Research Centre, Vilnius.

Žilinskas, G., Pupienis, D., Jarmalavičius, D., 2010. Possibilities of regeneration of Palanga coastal zone. Journal of Environmental Engineering and Landscape Management, 18: 95-101.

Žilinskas, G., Jarmalavičius, D., Pupienis, D., Fedorovič, J., 2016a. Methodological aspects of lithological anomalies identification in Spits coasts (in Lithuanian). In: Jăros ir krantu tyrimai 2016, (eds. R. Milerinè and E. Grinienè): 240-243. Klaipèda University Publishing House, Klaipeda

Žilinskas, G., Jarmalavičius, D., Damušytè, A., Pupienis, D., 2016b. Where there was Juodkrantè Strait during Post-Littorina time? (in Lithuanian). In: Jăros ir krantu tyrimai 2016 (eds. R. Milerinè and E. Grinienè): 235-239. Klaipèda University Publishing House, Klaipèda. 